\title{
Influence of Technological Factors on the Decomposition Process of Nitrous Oxide (I)
}

\author{
Denisova KO*, Ilyin AA, Rumyantsev RN and Ilyin AP \\ Ivanovo State University of Chemical Technology pr, Russia \\ *Corresponding author: Denisova KO, Ivanovo State University of Chemical Technology pr, Russia
}

\begin{tabular}{|c|c|}
\hline ARTICLE INFO & ABSTRACT \\
\hline Received: 幽 June 05, 2020 & Citation: Denisova KO, Ilyin AA, Rumyantsev RN, Ilyin AP. Influence of Technological \\
\hline Published: 蔧 June 19, 2020 & $\begin{array}{l}\text { Factors on the Decomposition Process of Nitrous Oxide (I). Biomed J Sci \& Tech Res } \\
28(3)-2020 \text {. BJSTR. MS.ID.004642. }\end{array}$ \\
\hline
\end{tabular}

\section{Mini Review}

Nitric acid production represents the largest source of $\mathrm{N}_{2} \mathrm{O}$ in chemical industry, with global annual emission of 23.7 million tons of $\mathrm{N}_{2} \mathrm{O}$ per year. $\mathrm{N}_{2} \mathrm{O}$ has a high impact on the environment as greenhouse gas and stratospheric ozone depletory [1]

In this production, the formation of nitrous oxide is possible along two chemical routes [2]:

1. During the oxidation of ammonia in the contact reactor nitrous oxide $\left(\mathrm{N}_{2} \mathrm{O}\right)$ is formed as by-product.

$4 \mathrm{NH}_{3}+4 \mathrm{O}_{2} \leftrightarrows 2 \mathrm{~N}_{2} \mathrm{O}+6 \mathrm{H}_{2} \mathrm{O}$

2. In the process of low-temperature catalytic reduction of nitrogen oxides with ammonia.

$$
\begin{aligned}
& 2 \mathrm{NH}_{3}+8 \mathrm{NO} \rightarrow 5 \mathrm{~N}_{2} \mathrm{O}+3 \mathrm{H}_{2} \mathrm{O} \\
& 4 \mathrm{NH}_{3}+3 \mathrm{O}_{2}+4 \mathrm{NO} \rightarrow 4 \mathrm{~N}_{2} \mathrm{O}+6 \mathrm{H}_{2} \mathrm{O}
\end{aligned}
$$

The efficiency of the catalytic reduction of nitrous oxide (I) is determined primarily by the activity of the catalyst used. The active site of $\mathrm{CoO}$-exchanged catalyst for $\mathrm{N}_{2} \mathrm{O}$ decomposition is well known as divalent $\mathrm{CoO}$ (II) cations which closely collaborate on the $\mathrm{N}_{2} \mathrm{O}$ splitting. Thus, the formation of CoO-O is a key to achieve better performance in the $\mathrm{N}_{2} \mathrm{O}$ decomposition. The catalyst preparation method plays an important role in controlling the catalyst activity [3]. The catalyst's activity towards $\mathrm{N}_{2} \mathrm{O}$ decomposition is often significantly affected by the various components such as $\mathrm{H}_{2} \mathrm{O}, \mathrm{O}_{2}$ in the flue gas. The catalyst activity inhibition from $\mathrm{H}_{2} \mathrm{O}$ and $\mathrm{O}_{2}$ should be paid serious attention to. Therefore, the effects of the components in the flue gas on the catalyst's activity have also been investigated in the study. Catalysts based on cobalt ferrite are highly active in the decomposition of nitrous oxide in the production of nitric acid. The residual nitrous oxide content depends on the selected process conditions. On the same catalyst, catalytic activity may vary. The paper presents the dependence of the degree of conversion on almost all technological factors: temperature, pressure, concentration of water vapor, $\mathrm{H}_{2}$ and $\mathrm{O}_{2}$.

As shown in Figure 1, when pressure increases to $1.1 \mathrm{MPa}$, the influence of the ratio of components in the catalyst becomes more significant in terms of catalytic activity. So, on cobalt ferrite of stoichiometric composition, a $50 \%$ degree of decomposition of $\mathrm{N}_{2} \mathrm{O}$ is observed at $478{ }^{\circ} \mathrm{C}$, and $100 \%$ at $548^{\circ} \mathrm{C}$. The increase in pressure leads to a significant decrease in the temperature range of the catalyst. At $255^{\circ} \mathrm{C}$, a $50 \%$ conversion of $\mathrm{N}_{2} \mathrm{O}$ is observed, and at 347 ${ }^{\circ} \mathrm{C}$ nitrous oxide is completely decomposed. Increasing the content of cobalt oxide to $44 \%$ in the catalyst makes it possible to reduce the temperature by half and to achieve complete decomposition of $\mathrm{N}_{2} \mathrm{O}$ at $36-45^{\circ} \mathrm{C}$, respectively. The reduction of nitrous oxide (I) contained in exhaust gases in various technologies can be carried out at pressure from 0.4 to $1.1 \mathrm{MPa}$ as it's presented in Figure 2 . For this reason, we conducted detailed studies on the effect of pressure on the decomposition of nitrous oxide. Figure 2 shows the dependences of the degree of decomposition of $\mathrm{N}_{2} \mathrm{O}$ on temperature and pressure. It is shown that increase in pressure from $0.1 \mathrm{MPa}$ to 1.1 MPa causes increase of degree of decomposition of nitrous oxide by 6 times. So, for example, at $310^{\circ} \mathrm{C}$ the degree of decomposition is $17 \%$ and $99.5 \%$ for 0.1 and $1.1 \mathrm{MPa}$ respectively. 


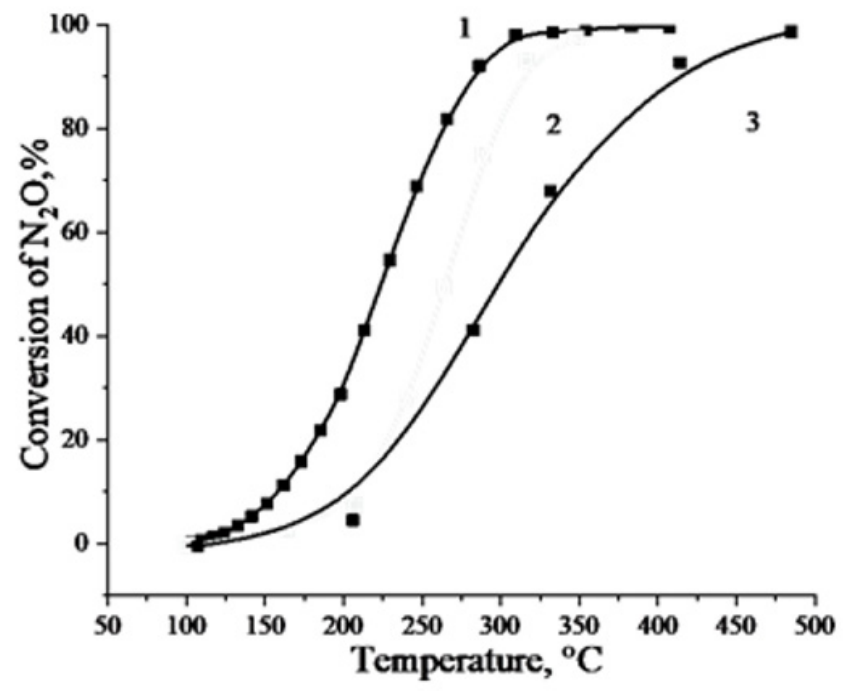

Figure 1: Catalytic activity of the catalyst based on $\mathrm{CoFe}_{2} \mathrm{O}_{4}$.

Note: $1-\mathrm{Fe}_{2} \mathrm{O}_{3}: \mathrm{CoO}=1.1 ; 2-\mathrm{Fe}_{2} \mathrm{O}_{3}: \mathrm{CoO}=0.6 ; 3-\mathrm{Fe}_{2} \mathrm{O}_{3}: \mathrm{CoO}=1$.

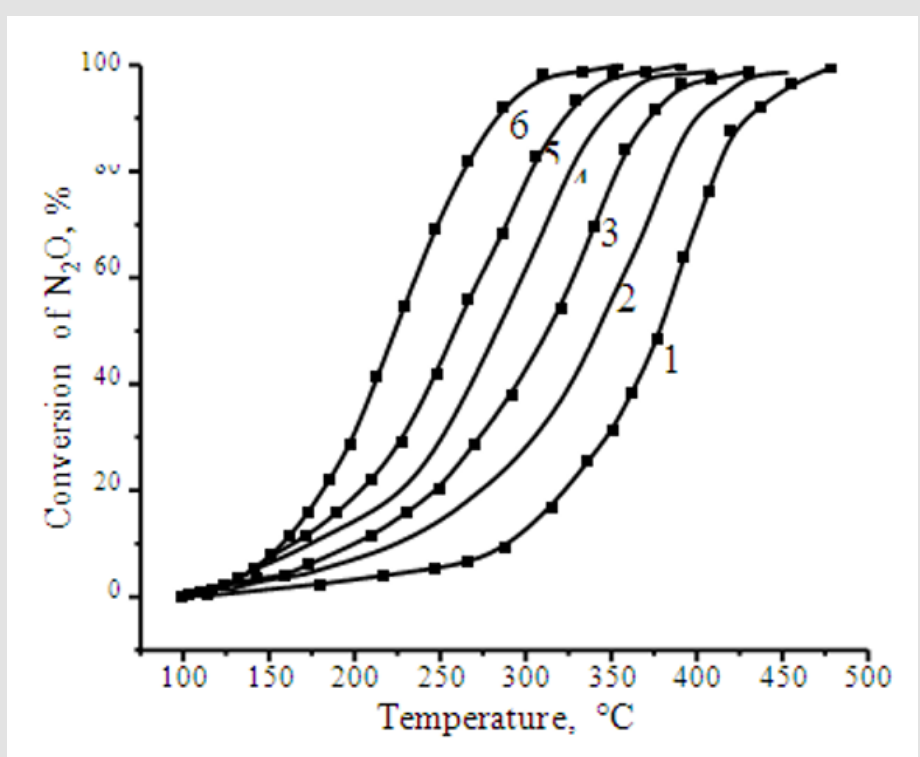

Figure 2: The effect of pressure on the decomposition of nitrous oxide.

Note: The pressure in the reactor: 1 - atm; 2 - 2 atm; 3-4 atm; 4 to $6 \mathrm{~atm} ; 5$ to 8 atm; $6-11$ atm.

Also, the effect of oxygen and water on the decomposition of $\mathrm{N}_{2} \mathrm{O}$ was observed. Water inhibition effect and oxygen one differs. Water simply blocks a catalyst's site. Role of oxygen could be presented in two stages. At the first stage of $\mathrm{N}_{2} \mathrm{O}$ decomposition reaction, oxygen competes with nitrous oxide for active sites. At the second stage $\mathrm{N}_{2} \mathrm{O}$ mixes with oxygen and starts recombination, which creates idle cycles. "The work was carried out as part of the state assignment for the implementation of research. Theme number FZZW-2020-0010 ».

\section{References}

1. Isupova LA, Ivanova Y (2019) Removal of nitrous oxide in the production of nitric acid. Kinetics and catalysis 60: 725-740.

2. Ilyin AP, Kunin AV (2013) Nitric acid production. p. 256.

3. Denisova K0, Ilin AA, Rumyantsev RN (2019) Nitrous oxide: Receipt, application, protection of environmental. Russian Journal of General Chemistry 89: 37-49. 
ISSN: 2574-1241

DOI: 10.26717/BJSTR.2020.28.004642

Denisova Ko. Biomed J Sci \& Tech Res

(C) (i) This work is licensed under Creative

Submission Link: https://biomedres.us/submit-manuscript.php

$\begin{array}{ll}\text { BIOMEDICAL } & \text { Assets of Publishing with us } \\ \text { RESEARCHES } & \text { - Global archiving of articles } \\ \text { - Immediate, unrestricted online access } & \text { - Rigorous Peer Review Process } \\ & \text { - Authors Retain Copyrights } \\ & \end{array}$

